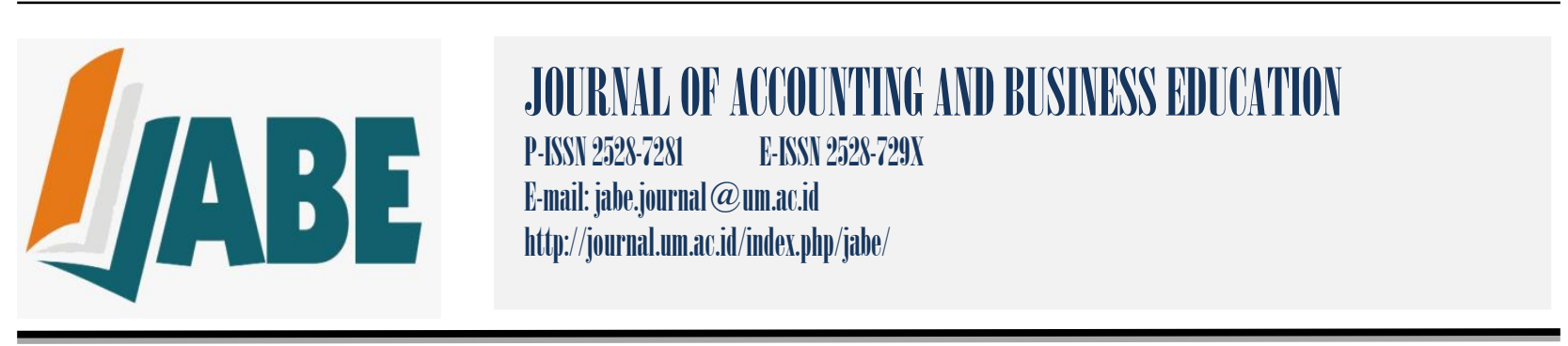

\title{
Development of Accounting E-Module to Support the Scientific Approach of Students Grade X Vocational High School
}

\author{
Imron Hamzah \\ Sriyani Mentari \\ Universitas Negeri Malang \\ hamzahimron1010@gmail.com
}

\begin{abstract}
Learning material development in form of electronic module with scientific is solution to optimize student's scientific thinking process in students. This electronic module development model uses ADDIE (Analysis, Design, Development and Implementation, Evaluation). Scientific approach to suports accounting e-module development is tested to students of grade X Accounting of SMK PGRI 2 Malang. Data type used is qualitative and quantitative. Test design used in scientific approach to suports e-module development is experimental. Data collection technique in this development uses polling. Research data analysis technique uses percentage descriptive technique, while qualitative data in form of critics and suggestion can directly make conclusion. Suports on scientific approach to suports accounting e-module development, from the result, it can be concluded that scientific approach to supports accounting e-module is appropriate and able to improve students learning motivation and result.
\end{abstract}

Keywords: E-Module, Scientific Approach, Learning motivation, Learning result.

\section{INTRODUCTION}

Based on Kemdikbud decision No. 160 of 2014 on the implementation of the 2013 curriculum, some schools implementing the 2013 curriculum must adapt to the curriculum. Teaching materials based on information and communication technology are ample to be used as a means of learning.

While the teaching materials must be in accordance with the standard competence of 2013 curriculum and there is an approach in the 2103 curriculum, namely the scientific approach. According to Daryanto (2014: 51), the scientific approach is a learning process designed in such a way that learners actively construct concepts, rules or principles through observing stages (to identify or find problems), formulate problems, propose or formulate hypotheses, collecting data 


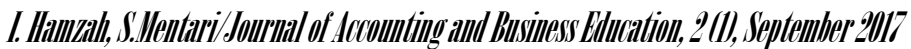

with various techniques, analyzing data, drawing conclusions and uttering concepts, the "found" principle.

The result of observations at SMK PGRI 2 Malang for 6 weeks in August to September 2016, shows that the school has provided facilities in the form of projector and sound for the learning process in all classes, yet the facility has not been utilized optimally. SMK PGRI 2 Malang has also enough libraries, however some books are old prints and not all of them in accordance with the 2013 curriculum.

In accounting learning process, teacher still manifests conventional methods that are lecturing, dictating, and frequently asking questions. Teachers still use printed materials, and students use printed books borrowed from school libraries. The goal of this e-module is to improve students' motivation and make the learning atmosphere more interesting, and also as teaching materials that can be used independently before or after the accounting learning in the class.

It can be reinforced by the result of interviews which have been conducted to accounting teachers and some students of grade X accounting major, SMK PGRI 2 Malang on November 4, 2016 and obtained findings, that students are more attracted in teaching materials contain images and video packed in fun teaching materials. The students also found it difficult to learn the process of recording, adjusting, and reversing journal of service company. Therefore, the researchers try to develop electronic module (e-module) to support the scientific approach. The goals of this e-module are to increase students' motivation to learn and to make the learning atmosphere more fun, and beneficial as teaching materials that can be used independently before or after the learning activities in the class.

In line with the research undertaken by (Ni Kadek Dina Agustina et al: 2015) "Pengembangan E-Modul Berbasis Metode PembelajaranProblem Based Learning pada Mata Pelajaran Pemrograman Dasar Kelas X Multimedia di SMK Negeri 3 Singaraja " this research shows the feasibility assessment of basic e-programming module according on content specialist, is marked as viable, design learning specialist is marked as highly eligible, media specialist is marked as viable, and the field trials of teachers and students fall into the very best category. Hence, from the assessment can be concluded that the basic programming e-modules based on Problem Based Learning is worth to be utilized for learning resources in SMK Negeri 3 
Singaraja grade $\mathrm{X}$ majoring multimedia, and is expected to help the performance of teachers in the learning process and students to learn independently in school or at home.

Next is the previous study by (Sitti Ghaliyah: 2015) "Pengembangan Modul Elektronik Berbasis Model Learning Cycle 7E Pada Pokok Bahasan Fluida Dinamik Untuk Siswa SMA Kelas IX “. The responses of grade XI students about physics e-module, shows the $84.45 \%$ percentage of achievement with measured aspects, namely e- module display format, Dynamic Fluid material content, and grammar. These results displays that the physics e-module of learning cycle $7 E$ model which has been developed can be very well received by students for independent learning materials before or after the physics learning activities in the class.

Supported with the research conducted by (Zulkarnain: 2015) entitled "Pengembangan E-Modul Teori AtomMekanika Kuantum Berbasis WebDengan Pendekatan Saintifik”, e-module is valid and feasible to use, yet on the aspect of klasikan mastery, the e-module is still ineffective with the mastery of substance only $58.06 \% \geq 85 \%$. The difference on the development of emodule to support this scientific approach in terms of products is said to be feasible and able to improve student learning outcomes and motivations, in terms of content it is also adjusted to 2013 curriculum that is to support the scientific approach.

Refers to the above background, the purpose of this research and development is to produce e-module of services company accounting to support the implementation of appropriate scientific approach used in the learning process that can improve motivation and outcomes the students of grade $\mathrm{X}$ vocational high school.

\section{LITERATURE REVIEW}

The theory of constructivism is a new theory of cognitive learning in psychology education that states the students must find their own and transform complex information, check new information with old rules and revise them if the rules are no longer appropriate. For students to truly understand and apply the knowledge, they must work to solve problems, find something for themselves, work hard with the ideas of Slavin 1994 (in Trianto, 2012: 74). Budiningsih (2015: 56) states that in a constructivist approach, knowledge is not a collection of facts from a reality being studied, but as a person's cognitive construct to the object, experience, and environment. 


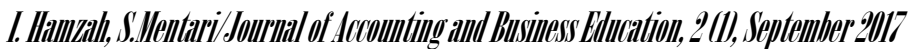

According to some sense of constructivist learning theory, it emphasizes that the students construct their own knowledge in learning activity. Students are required to be more independent, active and given the freedom to express their own opinions without any limitations.

The learning process in the module is a form of scientific approach. Abidin (2014: 132) says that, scientific learning process is defined as a learning model developed with scientific approach in the learning itself. It includes 1) observing, 2) questioning, 3) reasoning, 4) attempting, 5) analyzing and concluding, 6) communicating. The scientific approach is a learning model that requires students to think critically, actively and be able to solve their own problems.

Module is one of the teaching materials that can be benefited by the teacher to help the learning process. Teaching materials are learning materials in which there is a set of materials to support the flows of learning and learning activities to run properly. It is also defined by (Majid, 2009: 173) teaching materials are all forms of materials used to help teachers/instructors in carrying out teaching and learning activities. Module is a form of teaching materials that are packed intact and systematic, it contains a set of planned and designed learning experiences to help students master specific learning objectives (Daryanto, 2013: 9).

Agustina (2015: 3) says that e-module is a set of digital and non-print teaching media systematically arranged and used for self-study purposes, so it requires students to learn solving problems in their own way. E-module is a learning material that are systematically designed based on a particular curriculum and packaged in a certain time unit which displayed with electronic devices such as computer or android.

The differences of this study with previous research are in the approach used, the material contained and the view to be presented. This study uses a scientific approach to adjust the current curriculum. In addition, the main program used to arrange this e-module is, Aurora 3D Presentation software to produce an interactive module and is facilitated with 3D display (3 Dimensions).

\section{METHODS}

This research applies Research and Development as research design. Sukmadinata (2013: 164) states that research and development is a process or steps to develop a new product or to refine a product that already exists, which can be justified. This e-module development model 
employs ADDIE (Analysis, Design, Development and Implementation, Evaluation) adapted from Robert Maribe Branch 2009).

1. Analysis: Identify the probable causes for a performance gap

2. Design: Verify the desired performances and appropriate testing methods

3. Develop: Generate and validate the learning resources

4. Implement: Prepare the learning environment and engage the students

5. Evaluate: Assess the quality of instructional products and processes, both before and after implementation

According to Neolaka (2008: 208) data analysis is a statistical or non-statistical data processing to obtain results or research findings. The technique for analyzing quantitative data uses descriptive percentage technique, while the qualitative data in form of criticism and suggestion can be directly drawn to conclusion.

Table 1 scales and assessment criteria

\begin{tabular}{ll}
\hline Percentage & Information \\
\hline $\mathbf{8 0 \%}-\mathbf{1 0 0 \%}$ & Valid / Used \\
$\mathbf{6 0 \%} \mathbf{- 7 9 \%}$ & Simply Valid/ Used \\
$\mathbf{5 0 \%} \mathbf{- 5 9 \%}$ & Less Valid / Replaced \\
\hline $\mathbf{5 0 \%}$ & Invalid / Replaced \\
\hline
\end{tabular}

(Source: Sudjana \& Ibrahim, 2012: 129)

Based on above explanation, there are five alternative answers which in every question or statement in Likert scale, there are alternative answers, namely as follows.

Table 2 Criteria of Assessment Scale

\begin{tabular}{lll}
\hline Alphabet & Score & Information \\
\hline SA & 4 & Strongly agree \\
A & 3 & Agree \\
D & 2 & Disagree \\
SD & 1 & Strongly Disagree \\
\hline & (Source: Sugiyono, 2016)
\end{tabular}

Based on those criteria, e-module to support learning activities with scientific approach is said to be worth $60 \%$. While the e-module to support learning with scientific approach will be effective if the significance value from the paired t-test calculation is $<0.05$. 


\section{RESULTS}

The e- module development to support the scientific approach in this research employs ADDIE development model. The development model includes Analysis, Design, Development and Implementation, Evaluation.

The model covers: 1) Analyzing stage is done during teaching and learning process, interviewing the teacher teaches services company accounting and students' responses. The purpose of this introduction is to obtain aspect data. 2) The planning stage contains e-module framework prior to validation and revision which means designing the story board. Story Board is the initial design prior to further development and prior to product validation and revision. 3) The development and application stage of e-module is developed by applying the product framework that has been created at the beginning. The process of making this e-module utilizes Aurora 3D Presentation and Ispring and other supporting software. At this stage the finished product will go through several stages that must be done as follows: expert validation, revision phase I, revised product will then be tested as consideration to assess the program made, and revision phase II.

Table 3 Summary of Validation Results by Media Experts

\begin{tabular}{llll}
\hline No & Assessed Component & $\mathbf{( \% )}$ & Validity Criteria \\
\hline $\mathbf{1}$ & Technical Quality & 95.83 & Valid / Used \\
$\mathbf{2}$ & Material Presentation & 93.75 & Valid / Used \\
$\mathbf{3}$ & Feedback & 100 & Valid / Used \\
$\mathbf{4}$ & Exercise & 100 & Valid / Used \\
$\mathbf{5}$ & etc. & 100 & Valid / Used \\
\hline
\end{tabular}

Based on Table 3, the validation data of media expert was obtained from Lecturer of Educational Technology Faculty of Education State University of Malang, Mr. Henry Praherdhiono, held on April 26, 2017. It is known that the whole e-module with scientific approach can be declared as valid with average percentage of $97.50 \%$. Technical quality, material presentation, feedback, exercise, etc. that are used in e-module are appropriate and compatible with the design of e-module.

Table 4 Summary of Validation Results by Material Experts

\begin{tabular}{llll}
\hline No & Assessed Component & $(\boldsymbol{\%})$ & Validity Criteria \\
\hline $\mathbf{1}$ & Material Presentation & 92.50 & Valid / Used \\
$\mathbf{2}$ & Scientific Approach & 94.44 & Valid / Used \\
$\mathbf{3}$ & Exercise & 83.33 & Valid / Used \\
$\mathbf{4}$ & etc. & 75.00 & Simply Valid / Used \\
\hline
\end{tabular}


Based on Table 4, the validation by material expert presented in e- module using scientific approach is done by Drs. Sukowiyono as a teacher who teaches service company accounting grade X accounting major of SMK PGRI 2 Malang, conducted on April 25, 2017. The results of validation by material experts indicate that the materials contained in the e-module has been prepared and presented in accordance with the topics that has discussed as a whole, and the average value is $89.81 \%$.

Students also perform feasibility tests as users. The goal is to determine the feasibility of learning devices from the aspect of the user.

Table 5 Results Summary of Trial by Students as User on Small Group Test

\begin{tabular}{llll}
\hline No & Assessed Component & $\mathbf{( \% )}$ & Validity Criteria \\
\hline $\mathbf{1}$ & Technical Quality & 83.75 & Valid / Used \\
$\mathbf{2}$ & Scientific Approach & 79.00 & Simply Valid / Used \\
$\mathbf{3}$ & Feedback & 86.00 & Valid / Used \\
$\mathbf{4}$ & Exercise & 85.83 & Valid / Used \\
$\mathbf{5}$ & etc. & 85.00 & Valid / Used \\
\hline
\end{tabular}

Based on product test on grade X accounting major of SMK PGRI 2 Malang, it can be seen that developed technical quality, scientific approach, feedback, exercise, and others got value of $83,95 \%$. 4) Implementation stage is done by field trial which, the finished product that has been through the expert validation stage, small group test and revision phases 1 and 2 . At this stage, the product test is conducted to know the effectiveness of the product in improving the learning outcome and motivation. The trial was conducted only on grade X SMK PGRI 2 Malang.

Table 6 Results Summary of Validation by Student and Teacher as Users

\begin{tabular}{cccc}
\hline No & Assessed Component & $\mathbf{( \% )}$ & Validity Criteria \\
\hline $\mathbf{1}$ & Technical Quality & 83.79 & Valid / Used \\
$\mathbf{2}$ & Scientific Approach & 82.22 & Valid / Used \\
$\mathbf{3}$ & Feedback & 83.88 & Valid / Used \\
$\mathbf{4}$ & Exercise & 83.79 & Valid / Used \\
$\mathbf{5}$ & etc. & 87.03 & Valid / Used \\
\hline
\end{tabular}

Based on table 6 it is known that from the limited field trial, it can be declared valid as a whole with the average percentage of $84.02 \%$ so it can be summed that e-module can help students to learn accounting and is eligible for accounting learning. 5) From all stages begun with analyzing, designing, development and implementation stage, then all those stages must be evaluated. Evaluation phase is conducted to assess the quality of products and processes before and after the implementation of e- module to users (students). 


\section{DISCUSSION}

Based on the validation and effectiveness test on the learning medium, there will be discussed the research achievement for objectives that have been formulated. Validation results show that e-module to support learning with scientific approach is feasible as learning medium in a learning process. In the e-module that supports the scientific approach, it is developed based on constructivist learning theory, in which the role of students according to constructivist view is to discover and transform their own knowledge (Budiningsih 2015: 58-59). Students construct the knowledge through observing videos in form of presented material in the e-module independently. After observing the video, then the students associate it with the theory or information from various sources available in the e-module.

The first feasibility test is obtained from validation test by media experts that valued 97.5\% and categorized as very feasible. Nevertheless, the test takers gave suggestions that are, the video and exercise should be included in one package if possible, so it can facilitate student to operate. Refers to these suggestions, the indicator of presented material is still lower than the technical quality, feedback, exercise and others indicators. There are three aspects that get the highest percentage of $100 \%$. This summary can be seen in table 2 , which consists the results of validity test by media experts. Since there are three aspects get the highest percentage, hence the e-module is categorized as very feasible with suggested revisions.

The material feasibility test is obtained from the material expert validation test, which is $89.81 \%$ with the category of very feasible. However, there are some suggestions from the test takers that are, the material arrangement and the level of difficulty should be tailored to students and be made more specific. According to these suggestions, it is obtained that assessment criteria for indicator of other, has lower value compared with indicators of material presentation, scientific approach and practices. E-module is said to be feasible to support the scientific approach because it gets the highest value of assessment by material experts on the aspects of material presentation, the results can be seen in table 3, which is the results summary of validation by the material experts. Therefore, the e-module is said very feasible to use with suggested revisions.

The product feasibility test is obtained from small group experiment conducted on the students of grade $\mathrm{X}$ accounting major consists of 5 students, and it scores $83.95 \%$ with category 


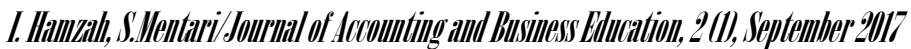

as very feasible. However, there are suggestions obtained from the test takers include, the emodule should be able for mobile devices so the usage is easier and the material should be made more specific, yet these do not reduce the percentage achieved. Based on these suggestions, it can be said that the percentage of the scientific approach indicator is the lowest among the percentage of technical quality, feedback, exercise and other indicators.

In the field trial, it was obtained two quantitative data, the first is the value of pre-test and post-test of grade $\mathrm{X}$ accounting major, to see the improvement of student learning outcomes, as well as the percentage of statement scores in the questionnaire given after the post-test. Pre-test is given before the students get and implement the learning, by doing paperwork. And post-test is done after students learn with e-module. From the pre-test and post-test, there is a significant increase in learning outcomes. In addition, e-module makes students able to learn all the materials for the second semester, therefore students can complete all the materials of the second semester. This is because the e-module has fulfilled one of the module criteria which is self contained. Modules are said to be self contained when all required learning materials are contained in the module Daryanto (2013). The e-module contains accounting for service companies materials in the second semesteras follows, adjusting journal material, work sheet material, financial statement material and the last is cover and reversing journal material. The purpose of this concept is to give students the opportunity to learn the materials thoroughly, because it is packed into a unified whole and will affect the learning outcomes.

The second stage is, to see the motivation improvement to learn, hence the students were given questionnaires before learning with e-module and after learning with e-module. Increased motivation can also be seen from the behavioral changes of students who are more active and interested to learn using e-module. The rise of percentage of field trial questionnaire is on the aspects of feedback and others. The feedback aspect gets percentage of $83,88 \%$ and other aspect includes the interest to electronic module, ease of operation and in terms of benefit the percentage is $87,03 \%$. It meets several module characteristics, one of which is self introduction Daryanto (2013). The characteristics are, practices, tasks, and the like which make it possible to measure the mastery of students and there is feedback on the assessment done by students.

According to some of these characters it can be said that, one aspect that can improve learning motivation by using e- module is, because students like e-module that contains practices 
that are easy to do and operate for measuring the mastery of them, and students can directly receive feedback on the practices done and they can know the level of material mastery.

Based on the results of product effectiveness test in improving learning outcomes by using paired samples t-test, it is obtained a significance of 0.000 . This shows that the e-module to support the scientific approach can improve student learning outcomes, while based on the product effectiveness test in the improvement of learning motivation by using paired samples ttest, it gets the significance of 0.000 . This suggests that e- module to support a scientific approach can improve students' learning motivation. Normality test and Paired Sample T-Test used SPSS 21.0 for Windows. The effectiveness test shows that e-module can improve learning outcomes and students' learning motivation.

\section{CONCLUSION}

Development of E-Module on Service Company Accounting Subject to Support the Scientific Approach in Improving Learning Outcomes and Motivation of Students Grade X SMK PGRI 2 Malang has been developed in accordance with the model developed by ADDIE (Analysis, Design, Development and Implementation, Evaluation) adapted from Robert Maribe Branch (2009).

E-module to support the learning with scientific approach can be seen from the assessment taken by the media expert $97,50 \%$, material expert $89,81 \%$, and user test (student) $83,95 \%$. In addition, accounting learning medium is also effective in improving learning outcomes and motivation. This can be seen from the analysis of Paired sample t-test on the average of student learning outcomes in before and after learning. Based on the test result, it was obtained a significance value of 0.00 . Therefore, based on these two tests, the e-module can be concluded as effective to be used as a learning medium.

As for some product development suggestions can be put forward as follows: 1) The next researchers are advised to make this e-module can be operated using android. 2) The next researchers are advisable to develop the practices on this e-module in various forms such as true or false or esay.3) The next researchers are also suggested to use the latest application in order to refine the finished product. 


\section{REFERENCES}

Abidin, Yunus. (2014). Desain Sistem Pembelajaran dalam Konteks Kurikulum 2013. Bandung: Refika Aditama.

Agustina, Ni Kadek Dina., dkk. (2015). Pengembangan E-Modul Berbasis Metode Pembelajaran Problem Based Learning pada Mata Pelajaran Pemrograman Dasar Kelas X Multimedia di SMK Negeri 3 Singaraja. Volume 4, No 5. (Online), (http://id.portalgaruda.org/index.php?ref=browse\&mod=viewarticle \&article=410288), diakses 30 Januari 2017.

Branch, Robert Maribe. (2009). Instructional Design: The ADDIE Approach. New York: Springer.

Budiningsih, C. Asri. (2015). Belajar dan Pembelajaran. Jakarta: PT Rineka Cipta.

Daryanto. (2013). Menyusun Modul. Yogyakarta. Gava Media.

Daryanto. (2014). Pendekatan Pembelajaran Saintifik Kurikulum 2013. Yogyakarta: Gava Media.

Ghaliyah, Sitti, dkk.. (2015). Pengembangan Modul Elektronik Berbasis Model Learning Cycle 7E Pada Pokok Bahasan Fluida Dinamik Untuk Siswa SMA Kelas IX. (Online), IV (http://snf-unj.ac.id/kumpulan-prosiding/snf2015/), diakses 31 Oktober 2016.

Kemdikbud. (2014). Permendikbud No 160 tahun 2014 tentang pemberlakuan kurikulum tahun 2006 dan kurikulum 2013 pada sekolah jenjang pendidikan dasar dan pendidikan menengah. Jakarta: Kemdikbud.

Majid, Abdul. (2009). Perencanaan Pembelajaran. Bandung: PT Remaja Rosdakarya.

Neolaka, Amos. (2014). Metode Penelitian dan Statistik: untuk Perkuliahan, Penelitian Mahasiswa Sarjana, dan Pascasarjana. Bandung: PT Remaja Rosdakarya.

Sudjana, Nana \& Ibrahim. (2012). Penelitian dan Penilaian Pendidikan. Bandung: Sinar Baru Algensindo.

Sugiyono. (2016). Metode Penelitian Kuantitatif, Kualitatif, dan R\&D. Bandung: Alfabeta.

Sukmadinata \& Nana Syaodih. (2013). Metode Penelitian Pendidikan. Bandung: PT Remaja Rosdakarya.

Trianto. (2012). Model Pembelajaran Terpadu. Jakarta: PT Bumi Aksara.Zulkarnain, Andi, dkk. ..(2015). Pengembangan E-Modul Teori Atom Mekanika Kuantum Berbasis Web Dengan $\begin{array}{llll}\text { Pendekatan Saintifik. } & \text { Vol.4, No.1. }\end{array}$ (http://id.portalgaruda.org/index.php?ref=browse \&mod=viewarticle \&article=328104), diakses 30 januari 2017. 